\title{
PENGEMBANGAN BAHAN AJAR KOMPILASI FISIKA MATEMATIKA II POKOK BAHASAN PERSAMAAAN DIFERENSIAL UNTUK MENINGKATKAN PENALARAN MATEMATIS
}

\author{
I Wayan Gunada, Joni Rokhmat, Hikmawati, Kesipudin \\ Program Studi Pendidikan Fisika \\ FKIP, Universitas Mataram \\ Jalan Majapahit No. 62, Mataram \\ E-mail: wayan_gunada@unram.ac.id
}

\begin{abstract}
This study aims to develop and produce teaching materials compilation of mathematical physics II on the subject of differential equations. Teaching materials that have been developed in the form of teaching modules. The research method used is a development study consisting of four stages: the stage of determination, design, development, and disseminate. The results obtained from this research are in the form of teaching module of mathematical physics II differential equation and its application. The teaching module generated in terms of feasibility aspects of content, presentation, and linguistics obtained amean score is 92.5 with a percentage is $79.74 \%$. This shows that the teaching module that has been created as good and feasible to use. It can be categorized effective as measured by the impact of student activities, responses, and value of students reasoning abilities. The impact of student activity seen during the learning process after using the module is $73.59 \%$ and the student activity is categorized much or quite practical. The percentage of students' response after using the module was $80.1 \%$ and categorized well. The impact on the mathematical reasoning ability meanscore of the class 70.87. This shows that the teaching module that has been created can be categorizedeffetive. Thus, it can be concluded that the teaching module compilation of mathematical physics II the subject of differential equations and their applications can be said to be effective and feasible to use.
\end{abstract}

Keywords: compilation, differential equations, mathematical reasoning.

\section{PENDAHULUAN}

Fisika matematika adalah gabungan mata pelajaran fisika dan matematika. Fisika matematika bertujuan agar mahasiswa memiliki kemampuan merumuskan berbagai proses fisika ke dalam pernyataan matematis dan mampu menyelesaikannya secara analitis, kuantitatif, dan prediktif berdasarkan model penalaran yang dirumuskan. Berdasarkan kurikulum pada Program Studi Pendidikan Fisika FKIP Universitas Mataram, matakuliah fisika matematika dipilah menjadi fisika matematika I dan fisika matematika II. Fisika matematika I materinya meliputi: deret pangkat dan deret tak hingga, analisis vektor, bilangan kompleks, sistem persamaan linier, matrik dan determinan, limit fungsi dan turunan, fungsi khusus (fungsi faktorial, fungsi gamma, fungsi beta, dan fungsi error). Sedangkan materi fisika matematika II meliputi: persamaan diferensial biasa, persamaan diferensial parsial, integral lipat, deret fourier, kalkulus variasi dan solusi deret persamaan diferensial. Kondisi ideal, yang diharapkan seorang dosen perlu mengorganisasikan materi ajar ke dalam bahan ajar sehingga capain pembelajaran dapat tercapai. Capaian pembelajaran yang diharapkan pada matakuliah ini adalah mahasiswa mampu mengaplikasikan bermacam konsep matematis untuk memecahkan berbagai permasalahan fisika.

Akan tetapi, capaian pembelajaran tersebut belum tercapai secara maksimal. Hal ini disebabkan oleh prilaku mahasiswa dalam mengikuti perkuliahan, diantaranya: 1) mahasiswa yang tidak mau melatih dirinya untuk mengerjakan soal-soal dalam buku,2) mahasiswa cenderung menghandalkan dari penjelasan dosen, 3) mahasiswa hanya 
menggunakan satu buku teks dan menggantungkan materi dari powerpoint dari dosen, dan 4) perilaku mahasiswa yang tidak mau belajar mandiri mencari sumber referensi yang menunjang matakuliah fisika matematika. Berdasarkan observasi selama proses perkuliahan, ada beberapa kesulitan yang dialami mahasiswa dalam mengikuti perkuliahan, diantaranya: 1) ketidakmampuan dalam menginterpretasi konsep-konsep fisika secara tepat, 2) ketidakmampuan mahasiswa menerapkan konsep-konsep dan prinsipprinsip fisika untuk memecahkan soal, dan 3) ketidakmampuan mahasiswa dalam mengaplikasikan konsep-konsep matematika untuk membuat model perumusan yang digunakan untuk pemecahan persoalan fisika. Sebagai salah satu contoh dari hasil penelitian Wahyudi (2015) mengungkapkan bahwa mahasiswa tidak bisa menentukan arus listrik pada rangkaian tertutup satu loop dengan dua atau lebih sumber tegangan, atau dengan hambatan listrik. Padahal secara konsep dan perhitungan matematis yang tepat, hal tersebut bisa dilakukan. Semua dampak tersebut, mengakibatkan kemampuan penalaran dan hasil belajarnyapun menjadi menurun.

Peningkatan kualitas pendidikan dapat dilakukan dengan meningkatkan kualitas proses pembelajaran. Hal tersebut dapat dicapai apabila ketersediaan bahan ajar yang cukup, penerapan strategi pembelajaran yang tepat, dan sistem evaluasi yang baik. Akan tetapi, selama ini di program studi hanya hanya menghandalkan buku Mathematical Methods in the Physical Sciences tulisan Mary L. Boas sebagai buku utama. Padahal seperti yang diungkapkan oleh Ellianawati dan Wahyuni (2012) bahwa contoh penerapan dan pembahasannya pada buku teks matakuliah fisika matematika yaitu Mathematical Methods in the Physical Sciences tulisan Mary L. Boas setebal 839 halaman masih kurang. Hal ini mengindikasikan, perlu adanya bahan ajar fisika matematika yang lebih banyak berisi contoh soal serta pembahasannya.

Sebaran materi kuliah fisika matematika II meliputi: persamaan diferensial biasa, persamaan diferensial parsial, integral lipat, deret fourir, kalkulus variasi dan solusi deret persamaan diferensial. Dari semua materi tersebut, materi persamaan diferensial yang paling banyak digunakan untuk membantu memecahkan permasalahan fisika. Berikut diberikan beberapa contoh fenomena alam yang dapat dimodelkan dalam bentuk persamaan diferensial, misalnya, pertumbuhan arus dalam rangkaian R-L. Rangkaian RL adalah sebuah rangkaian yang memasukan sebuah resistor dan sebuah inductor, dan mungkin sebuah sumber tegangan gerak elektrik, rangkaian tersebut dinamakan rangkaian R-L (R-L circuit) (Young, et. al., 2003). Menurut Nuraeni, (2017) persamaan diferensial juga dapat diaplikasikan untuk menghitung estimasi jumlah populasi. Selain itu persamaan diferensial dapat digunakan pula pada peluruhan radioaktif, hukum newton tentang gerak, system pegas, kelistrikan, termodinamika dan model ayunan. Pada hakekatnya persamaan diferensial dapat membantu memecahkan permasalahan fisika, sehingga materi persamaan diferensial ini perlu dikembangkan dengan mengkompilasi dari berbagai sumber. Seperti penelitian Murdiyanto, (2016) yang mengembangkan bahan ajar kompilasi persamaan diferensial elementer yang berupa RPKPS, handout,power point, dan contoh soal serta pembahasanya.

Persamaan differensial adalah persamaan yang memuat turunan suatu fungsi atau diferensial suatu variabel (Arjudin, 2005). Sedangkan menurut Lestari (2013) Persamaan diferensial adalah suatu bentuk persamaan yang memuat derivatif (turunan) satu atau lebih variabel tak bebas terhadap satu atau 
lebih variabel bebas suatu fungsi. Persamaan diferensial sangat penting di dalam matematika untuk rekayasa sebab banyak hukum dan hubungan fisik muncul secara matematis dalam bentuk persamaan diferensial. Persamaan diferensial (disingkat PD) diklasifikasikan dalam dua kelas yaitu biasa dan parsial. Persamaan diferensial biasa (ordinary differential equation) disingkat PDB adalah suatu persamaan diferensial yang hanya mempunyai satu variabel bebas. Sedangkan persamaan diferensial parsial (disingkat PDP) adalah suatu persamaan diferensial yang mempunyai dua atau lebih variabel bebas.

Begitu pentingnya aplikasi persamaan diferensial. Oleh sebab itu, pada pembelajaran fisika matematika perlu dikembangkan bahan ajar fisika matematika pokok bahasan persamaan diferensial yang dapat meningkatkan penalaran matematis mahasiswa, karena dengan penalaran matematis ini akan membantu mahasiswa dalam menyimpulkan dan membuktikan suatu pernyataan, membangun gagasan baru, sampai pada menyelesaikan masalah-masalah dalam fisika dengan menggunakan torema matematika. Seperti yang diungkapkan Amilia, et.al., (2016) menyatakan bahwa fisika matematika merupakan mata kuliah yang menuntut mahasiswa untuk dapat menganalisis berbagai persoalan fisika dengan penguasaan konsep matematis. Konsep yang muncul disetiap bidang ilmu pasti merupakan hasil dari suatu proses penalaran, terlebih dalam mata kuliah fisika matematika II. Penalaran matematika adalah penalaran mengenai objek matematika. Objek matematika dalam hal ini adalah cabang-cabang matematika yang dipelajari seperti statistika, aljabar, geometri, dan sebagainya. Suharnan (2005), mengungkapkan bahwa penalaran disebut juga sebagai jalan pikiran. Menurut NCTM (2000), dalam Septian (2014) mengungkapkan dalam bukunya Principle and Standards for School Mahtematics, standar penalaran matematis meliputi: penalaran dipandang sebagai aspek dasar matemtaik, membuat dan menyelidiki dugaan matematik, mengembangkan dan melakukan evaluasi argumen matematik, serta menggunakan berbagai tipe penalaran.

Melihat paparan tersebut, salah satu cara yang dapat dilakukan dalam mengembangkan bahan ajar adalah dengan mengkompilasi. Menurut Paulina dan Purwanto (2005), dalam Murdiyanto (2016) mengkompilasi adalah mengumpulkan seluruh bahan atau materi pelajaran yang diambil dari buku teks, jurnal ilmiah, artikel, dan lain-lain. Proses penataan informasi (kompilasi) bahan ajar dapat dikumpulkan dari berbagai sumber informasi, baik dari penelitian sendiri atau ditulis sendiri dan digabungkan dengan informasi-informasi yang telah ada.

Pengembangan bahan ajar fisika matematika telah banyak dilakukan oleh para peneliti, diantaranya penelitian pengembangan bahan ajar fisika matematika Berbasis Self Regulated Learning sebagai upaya meningkatkan kemampuan belajar mandiri oleh Ellianawati dan Wahyui (2012) dan hasilnya bahan ajar yang dihasilkan berkategori baik. Penelitian yang terkait dengan matakuliah fisika matematika, juga dilakukan oleh Fatmaryanti (2014) dan hasilnya bahwa metode brainstorming dan tutor sebaya dapat meningkatkan aktivitas dan hasil belajar fisika matematika I. Amilia, et.al., (2016) juga melakukan penelitian pengembangan bahan ajar cetak matakuliah fisika matematika pokok bahasan bilangan komplek dan menghasilkan bahan ajar cetak fisika matematika pokok bahasan bilangan komplek yang dikategorikan valid dan layak.

Bertitik tolak dari paparan tersebut dan pemikiran untuk meningkatkan penalaran matematis mahasiswa dan memudahkan dosen 
untuk mengajar dikelas maka peneliti terdorong untuk melakukan penelitian pengembangan. Hasil pengembangan bahan ajar berupa: modul ajar kompilasi fisika matematika II pada pokok bahasan persamaan diferensial dan aplikasinya. Modul ajar yang dimaksud dalam penelitian ini, adalah buku dalam bentuk modul-modul terpisah sesuai dengan pokok bahasan, disusun berdasarkan rancangan pembelajaran, dan disebarluaskan pada peserta kuliah.Modul merupakan bahan ajar yang ditulis dengan tujuan agar peserta didik dapat belajar secara mandiri.

\section{METODE PENELITIAN}

Penelitian ini dilaksanakan di Jurusan Pendidikan Fisika FKIP Universitas Mataram. Subjek penelitian ini adalah mahasiswa pendidikan fisika yang menempuh mata kuliah fisika matematika II semester genap 2016/2017. Penelitian ini termasuk jenis penelitian pengembangan pendidikan (Educational Research and Development). Model yang digunakan, adalah model 4-D (define, design, develop, disseminate). Penelitian jenis ini digunakan untuk menghasilkan bahan ajar atau seperangkat dengan tujuan tertentu (Gunada, et.al., 2015; Habibi \& Herayanti, 2016). Produk penelitian ini adalah bahan ajar kompilasi fisika matematika II pokok bahasan persamaan diferensial. Bahan ajar yang dikembangkan berupa modul ajar. Tahap pengembangan meliputi: tahap define, tahap design, tahap develop, dan tahap disseminate.

Pada tahap define (penetapan) dilakukan studi pendahuluan yang terdiri dari analisis kurikulum program studi pendidikan fisika, analisis materi, analisis karakteristik peserta didik (mahasiswa) dan analisis capaian pembelajaran mata kuliah (CPMK). Tahap analisis kebutuhan dilakukan untuk melihat gambaran kondisi di lapangan yang berkaitan dengan proses pembelajaran fisika matematika pada pokok bahasan persamaan diferensial. Proses yang dilakukan antara lain: (1) menganalisis silabus mata kuliah Fisika Matematika II, (2) menganalisis buku-buku ajar yang berisi materi persamaan diferensial, untuk melihat kesesuaian isi buku dengan learning outcomes yang harus dicapai mahasiswa, (3) Mereview literatur yang terkait dengan pengembangan bahan ajar kompilasi.

Tahap design (perancangan) dilakukan untuk menetapkan format modul ajar yang sesuai dengan standar, sehingga menghasilkan draf modul. Pada tahap ini, kegiatan yang dilakukan adalah merancang modul ajar. Produk yang dihasilkan pada tahap ini adalah modul ajar fisika matematika II pokok bahasan persamaaan diferensial dan aplikasinya.

Tahap selanjutnya, tahap develop (pengembangan). Pada tahap ini meliputi: (1) validasi modul untuk mengetahui kelayakan modul, dan (2) menguji efektifitas modul dilihat dari aspek aktivitas mahasiswa saat menggunakan modul, respon mahasiswa, dan nilai kemampuan penalaran matematis. Tahap validasi modul dilakukan untuk memvalidasi komponen kelayakan isi, penyajian dan kebahasaan. Validasi ahli dilakukan menggunakan instrumen lembar validasi. Modul ajar yang diberikan kepada reviewer untuk dicermati. Skor hasil validasi, terhadap seluruh aspek yang dinilai dihitung skornya dan dibagi dengan skor maksimal, kemudian dicari prosentasennya. Prosentase yang hasilnya dikonfirmasikan dengan kriteria yang ditetapkan pada tabel 1 . Lembar angket untuk validasi ahli menggunakan skala Likert yaitu: baik sekali skor 4, baik skor 3, kurang skor 2, dan kurang sekali skor 1. Analisis kelayakan modul ajar menggunakan rentang skor sebagai berikut (Murdiyanto, 2016). 
Tabel 1. Nilai Persentase Kelayakan Modul Ajar

\begin{tabular}{ccc}
\hline No. & Interval & Kriteria \\
\hline 1. & $81 \%-100 \%$ & Sangat Baik \\
2. & $61 \%-80 \%$ & Baik \\
3. & $41 \%-60 \%$ & Cukup \\
4. & $21 \%-40 \%$ & Kurang Baik \\
5 & $0 \%-20 \%$ & Sangat Kurang \\
\hline
\end{tabular}

Tahap II, uji efektivitas modul ajar dilakukan, setelah modul yang dibuat dimplementasikan pada proses perkuliahan. Keefektifan modul ajar diukur oleh tiga indikator yaitu aktivitas mahasiswa, tes kemampuan penalaran matematis, dan respon mahasiswa. Pada uji coba ini, diamati aktivitas belajar melalui observasi, kemampuan penalaran diperoleh dari hasil tes, dan respon mahasiswa. Data aktivitas mahasiswa diperoleh dengan cara menghitung jumlah mahasiswa yang melakukan aktivitas menggunakan lembar observasi. Data tersebut dianalisis dengan teknik persentase yang dinyatakan dengan rumus $\mathrm{P}=\mathrm{f} / \mathrm{N} \times 100 \%$ dimana $\mathrm{P}$ adalah persentase aktivitas, $\mathrm{f}$ adalah jumlah mahasiswa beraktivitas, dan $\mathrm{N}$ adalah jumlah mahasiswa.

Untuk mengetahui tingkat keberhasilan aktivitas belajar mahasiswa, dilakukan dengan menghitung prosentase skor rata-rata (SR) tiap pertemuan. Setelah data diperoleh, dianalisis, dan dihitung prosentase skor rata-rata hasil observasi. Kemudian skor rata-rata (SR) diklasifikasikan: (a) sangat baik, jika persentase skor rata-rata (SR) lebih besar dari 85; (b) baik, jika persentase skor rata-rata (SR) lebih besar dari 70 tetapi kurang dari 85; (c) cukup baik jika persentase skor rata-rata (SR) lebih besar dari 55 tetapi kurang dari 70; (d) kurang baik jika jika persentase skor rata-rata (SR) lebih besar dari 40 tetapi kurang dari 55; (e) tidak baik, jika persentase skor rata-rata (SR) kurang dari 40 (Farman, 2017).

Tes penalaran matematis dipergunakan untuk mengetahui sejauhmana pengaruh penggunaan modul ajar persamaaan diferensial, dapat meningkatkan kemampuan penalaran matematis. Penggunakan penilaian tes penalaran matematis yang berjumlah 20 butir soal. Tes penalaran matematis terdiri atas penalaran induktif dan deduktif. Tes diberikan kepada 23 orang mahasiswa yang digunakan sebagai kelas ujicoba (kelas B). Kriteria hasil tes penalaran mahasiswa, menurut Parman (2017) dapat diklasifikasikan sebagai berikut: (a) sangat tinggi, jika pencapaian penalaran mahasiswa (PPM) lebih besar dari 85; (b) tinggi, jika PPM lebih besar dari 70 tetapi kurang dari 85; (c) sedang jika PPM lebih besar dari 55 tetapi kurang dari 70; (d) rendah jika PPM lebih besar dari 40 tetapi kurang dari 55; (e)sangat rendah, jika PPM kurang dari 40.

Angket respon mahasiswa digunakan, untuk mengukur pendapat mahasiswa terhadap modul ajar dan kegiatan pembelajaran. Angket respon terdiri dari sepuluh butir pertanyaa dan empat pilihan jawaban yaitu: sangat setuju (SS) skor 4, setuju (S) skor 3, kurang setuju (KS) skor 2, dan tidak setuju (TS) skor 1. Data hasil respon dianalisis dengan tahapan sebagai beikut: (1) merekap skor setiap mahasiswa, (2) mengkonversi skor tiap-tiap mahasiswa kedalam rentang nilai 0100. Kemudian langkah (3) menghitung ratarata respon seluruh responden $(\bar{s})$ dan (4) membuat kesimpulan. Jika yang muncul adalah menerima (respon positif) atau menolak (respon negatif). Atas dasar alasan ini, rentang nilai 0 -100 hanya dibagi 2 , yaitu $0 \leq \bar{s} \leq 50$ dan $51 \leq \bar{s} \leq 100$. Kriteria respon mahasiswa ditentukan dengan (a) jika rata-rata respon seluruh responden $(\bar{s})$ lebih besar dari 50, maka subjek ke -i memberi respon positif, (b) jika rata-rata respon seluruh responden $(\bar{s})$ lebih kecil dari 50, maka subjek ke -i memberi respon negatif. Indikator keberhasilan penelitian yaitu: (1) modul ajar dikatakan layak, jika prosentase nilai rata-rata dari reveiwer $(60 \%-79 \%)$ kategori baik atau $(80 \%$ - 
100\%) kategori sangat baik; (2) modul dikatakan efektif jika, aktivitas belajar baik atau sangat baik, penalaran mahasiswa tinggi atau sangat tinggi, dan mendapat respon positif dari mahasiswa.

\section{HASIL DAN PEMBAHASAN}

\section{A. Tahap Define (Pendefinisan).}

Berdasarkan analisis tujuan dan karakteristik matakuliah, memperlihatkan bahwa matakuliah fisika matematika II diprogram pada semester gasal, dengan bobot 4 sks. Berdasarkan analisis sumber belajar mahasiswa diperoleh gambaran bahwa mahasiswa hanya tergantung pada buku
Mathematical Methods in the Physical Sciences. Analisis karakteristik mahasiswa, diperoleh gambaran ternyata cara belajar mahasiswa hanya menghandalkan penjelasan dari dosen, kurang melatih diri, dan tidak bisa belajar mandiri. Sasaran belajar atau capaian pembelajaran dituangkan dalam capaian pembelajaran mata kuliah (CPMK). Berdasarkan hasil analisis materi dari berbagai sumber diantaranya, buku fisika dasar universitas, elektonika dasar, fisika modern, kalkulus, fisika matematika, ternyata diperoleh gambaran aplikasi materi fisika matematika II dalam fisika (Tabel 2).

Tabel 2. Sebaran Materi Mata Kuliah Fisika Matematika II dan Aplikasinya.

\begin{tabular}{|c|c|c|}
\hline No & Materi & Aplikasi dalam Fisika \\
\hline 1 & $\begin{array}{l}\text { Persamaan } \\
\text { diferensial biasa }\end{array}$ & $\begin{array}{l}\text { - Aplikasi pada rangkaian listrik RL. } \\
\text { - Aplikasi pada rangkaian listrik RC. } \\
\text { - Aplikasi dalam peluruhan radioaktif. } \\
\text { - Aplikasi dalam pertumbuhan populasi. } \\
\text { - Aplikasi dalam Hukum Pendinginan Newton . } \\
\text { - Aplikasinya membahas persamaan dinamika satu dimensi yang dijumpai } \\
\text { dalam sistem partikel bermassa yang terhubung dengan pegas }\end{array}$ \\
\hline 2 & $\begin{array}{l}\text { Persamaan } \\
\text { diferensial parsial }\end{array}$ & $\begin{array}{l}\text { - Aplikasinya menyelesaikan persamaan gelombang. } \\
\text { - Aplikasi dalam hubungan Maxwell dalam termodinamika. }\end{array}$ \\
\hline 3 & Integral lipat & $\begin{array}{l}\text { Aplikasi untuk menghitung massa total suatu benda, jika diketahui } \\
\text { fungsi rapat massa. } \\
\text { - Menghitung titik pusat massa dan momen inersia dari sumbu putar suatu } \\
\text { benda. } \\
\text { Aplikasi dalam listrik magnet, yaitu untuk menghitung kuat medan dan } \\
\text { potensial pada suatu titik. }\end{array}$ \\
\hline 4 & Deret fourir & $\begin{array}{l}\text { Aplikasi pada gelombang yang berfungsi untuk menentukan frekuensi } \\
\text { dari suatu sinyal suara atau cahaya. }\end{array}$ \\
\hline 5 & Kalkulus variasi & $\begin{array}{l}\text { Prinsip Hamilton memiliki peranana yang cukup penting dalam } \\
\text { mekanika, gelombang maupun dalam teori medan. }\end{array}$ \\
\hline 6 & $\begin{array}{l}\text { Solusi deret } \\
\text { persamaan } \\
\text { diferensial }\end{array}$ & $\begin{array}{l}\text { Aplikasinya sebagai contoh kemuculan PDB Legendre dan Bessel, kita } \\
\text { tinjau persamaan Maxwell untuk divergensi medan listrik skalar dalam } \\
\text { vakum yang dinyatakan dalam formulasi medan skalar, dimana } \\
\text { persamaan diferensial terkaitnya berbentuk persamaan Laplace }\end{array}$ \\
\hline
\end{tabular}

Berdasarkan analisis CPMK, KA, dan sebaran materi fisika matematika II, terlihat bahwa pokok bahasan persamaan diferensial biasa, paling banyak diaplikasikan dalam penyelesaian permasalahan fisika. Meskipun pokok bahasan lainnya seperti persamaan diferensial parsial, integral lipat, deret fourier, kalkulus variasi, dan materi solusi deret persamaan diferensial, juga bermanfaat dalam fisika. Analisis CPMK, KA, dan sebaran pokok bahasan ini, yang dijadikan pertimbangan peneliti, untuk mengembangkan pokok bahasan persamaan diferensial. Kompilasi yang dimaksud, dalam hal ini 
adalah mengumpulkan materi dari berbagai sumber. Modul ajar fisika matematika II pokok bahasan persamaan diferensial disusun dalam rangka untuk membantu mahasiswa dalam memahami konsep dan aplikasi matematika dasar untuk memecahkan permasalahan-permasalahn fisika. Modul ajar persamaan diferensial dan aplikasinya disusun untuk menunjang mata kuliah lain yang membutuhkan aplikasi persamaan diferensial, dan membantu mengembangkan kemampuan mahasiswa dalam berpikir analitis kuantitatif berdasarkan pola penalaran matematis logis dalam memecahkan setiap persoalan fisika.

\section{B. Tahap Design (Perancangan).}

Pada tahap ini, di hasilkan draf modul ajar fisika matematika II pada pokok bahasan persamaan diferensial dan aplikasinya. Tahap penyusunan drap modul meliputi: merancang deskripsi matakuliah, petunjuk penggunaan modul, capaian pembelajaran perkuliahan (course learning outcomes) dan indikator pada masing-masing modul. Pada tiap modul secara umum berisi: deskripsi modul, penyajian materi, rangkuman, dan latihan soal. Modul ajar terdiri atas lima (5) modul yang tertuang dalam 74 halaman. Adapun rincian drafnya dapat dilihat pada Tabel 3.

Tabel 3. Draf Modul Ajar

\begin{tabular}{|c|c|c|}
\hline 1 & Judul Modul Ajar : & Modul Ajar Fisika Matematika II Persamaan Diferensial dan Aplikasinya \\
\hline II & $\begin{array}{l}\text { Petunjuk } \\
\text { Penggunaan } \\
\text { Modul }\end{array}$ & $\begin{array}{l}\text { 1. Pelajari dan pahami terlebih dahulu dengan tepat capaian pembelajaran } \\
\text { (Learning Outcomes) mata kuliah, kemampuan akhir (KA), dan indikator } \\
\text { keberhasilan }\end{array}$ \\
\hline
\end{tabular}

2. Baca dan pelajari secara menyeluruh sistematika isi dan materi pembelajaran, rangkuman, uji kemampuan kognitif, dan latihan/tugas.

3. Peran dosen adalah memberikan bimbingan dan memotivasi aktivitas mahasiswa selama proses pembelajaran. Selanjutnya mahasiswa secara aktif dan kreatif untuk mengembangkan potensinya sehingga pengkajian terhadap setiap bagian dari isi pesan modul ajar ini bermakna dan tidak hanya pada tataran teoritis melainkan juga memberikan kemampuan memecahkan masalah fisika.

4. Dosen mengupayakan pendekatan pembelajaran mandiri yang mendorong kemandirian mahasiswa dalam mengerjakan setiap latihan/tugas sesuai tuntutan pada setiap modul.

\begin{tabular}{lll}
\hline III Isi & Modul I & Konsep Dasar Persamaan Diferensial \\
\hline & Modul II Persamaan Diferensial Biasa Orde I \\
\hline & Modul III Aplikasi Persamaan Diferensial Orde I \\
\hline & Modul IV Persamaan Diferensial Biasa Orde I \\
\hline & Modul V Persamaan Cauchy Euler \\
\hline
\end{tabular}

\section{Tahap Develop (Pengembangan).}

Tahap ini, modul ajar yang telah dibuat kemudian diuji dengan dua tahap yaitu: uji validitas produk dan uji efektifitas produk. Uji validitas produk digunakan untuk menilai kelayakan modul. Sedangkan uji efektifitas produk dilihat dari hasil aktivitas mahasiswa, respon mahasiswa, dan hasil ujicoba modul terhadap kemampuan penalaran matematis.

\section{Uji Validitas Produk}

Modul yang telah dibuat, kemudian direveiw melalui angket yang berisikan pernyataan dengan skala penilaian 1 sampai 4 yang kelompokkan dalam tiga aspek yaitu (1) aspek kelayakan isi, (2) penyajian, dan (3) kebahasaan. Tabulasi hasil validasi oleh para ahli, selengkapnya dapat dilihat pada Tabel 5, 6, dan 7 . 
Tabel 5. Tabulasi Skor Komponen Kelayakan Isi

\begin{tabular}{|c|c|c|c|c|c|c|c|c|c|c|c|}
\hline \multirow{3}{*}{ No } & \multirow{3}{*}{ Butir } & \multicolumn{5}{|c|}{ Reviewer I } & \multicolumn{5}{|c|}{ Reviewer II } \\
\hline & & \multicolumn{4}{|c|}{ Skala Skor } & \multirow[t]{2}{*}{ Skor } & \multicolumn{4}{|c|}{ Skala Skor } & \multirow[t]{2}{*}{ Skor } \\
\hline & & 1 & 2 & 3 & 4 & & 1 & 2 & 3 & 4 & \\
\hline \multicolumn{12}{|c|}{ I. Komponen Kelayakan Isi } \\
\hline 1 & $\begin{array}{l}\text { Menjelaskan capaian pembelajaran } \\
\text { (learning outcomes) yang dicapai } \\
\text { oleh peserta didik. }\end{array}$ & & & $\sqrt{ }$ & & 3 & & & & $\sqrt{ }$ & 4 \\
\hline 2 & $\begin{array}{l}\text { Menjelaskan relevansi isi modul } \\
\text { dalam kegiatan pembelajaran. }\end{array}$ & & & $\sqrt{ }$ & & 3 & & & $\sqrt{ }$ & & 3 \\
\hline 3 & Diskripsi cakupan isi modul ajar. & & & $\sqrt{ }$ & & 3 & & & $\sqrt{ }$ & & 3 \\
\hline 4 & $\begin{array}{l}\text { Kontribusi dari hasil penelitian atau } \\
\text { catatan penulis. }\end{array}$ & & & $\sqrt{ }$ & & 3 & & & $\sqrt{ }$ & & 3 \\
\hline Sul & total skor kelayakan isi & & & & & 12 & & & & & 13 \\
\hline $\operatorname{Pr}$ & sentase & & & & & $75,00 \%$ & & & & & $81,25 \%$ \\
\hline
\end{tabular}

Tabel 6. Tabulasi Skor Komponen Penyajian

\begin{tabular}{|c|c|c|c|c|c|c|c|c|c|c|c|}
\hline \multirow{3}{*}{ No } & \multirow{3}{*}{ Butir } & \multirow{2}{*}{\multicolumn{4}{|c|}{$\begin{array}{l}\text { Reviewer I } \\
\text { Skala Skor }\end{array}$}} & \multicolumn{6}{|c|}{ Reviewer II } \\
\hline & & & & & & \multirow{2}{*}{ Skor } & \multicolumn{4}{|c|}{ Skala Skor } & \multirow{2}{*}{ Skor } \\
\hline & & 1 & 2 & 3 & 4 & & 1 & 2 & 3 & 4 & \\
\hline \multicolumn{12}{|c|}{ I I. Komponen Penyajian } \\
\hline 1 & Konsistensi sistematika sajian modul & & & $\sqrt{ }$ & & 3 & & & $\sqrt{ }$ & & 3 \\
\hline 2 & Kelogisan penyajian & & & $\sqrt{ }$ & & 3 & & & $\sqrt{ }$ & & 3 \\
\hline 3 & $\begin{array}{l}\text { Kejelasan contoh-contoh yang } \\
\text { diberikan di sertai dengan strategi } \\
\text { pemecahan masalah }\end{array}$ & & & & $\sqrt{ }$ & 4 & & & $\sqrt{ }$ & & 3 \\
\hline 4 & Keruntutan Konsep & & & $\sqrt{ }$ & & 3 & & & $\sqrt{ }$ & & 3 \\
\hline 5 & Koherensi & & & $\sqrt{ }$ & & 3 & & & $\sqrt{ }$ & & 3 \\
\hline 6 & $\begin{array}{l}\text { Kesesuaian dan ketepatan ilustrasi } \\
\text { dengan materi }\end{array}$ & & & $\sqrt{ }$ & & 3 & & & $\sqrt{ }$ & & 3 \\
\hline 7 & Ada uraian singkat pada awal modul & & & & $\sqrt{ }$ & 4 & & & & $\sqrt{ }$ & 4 \\
\hline 8 & Contoh-contoh soal dalam setiap modul & & & & $\sqrt{ }$ & 4 & & & & $\sqrt{ }$ & 4 \\
\hline 9 & Daftar tetapan (konstanta) alam & & $\sqrt{ }$ & & & 2 & & $\sqrt{ }$ & & & 2 \\
\hline 10 & $\begin{array}{l}\text { Rujukan/sumber acuan termasa (up to } \\
\text { date) untuk teks, tabel, gambar, dan } \\
\text { lampiran }\end{array}$ & & & $\sqrt{ }$ & & 3 & & & $\sqrt{ }$ & & 3 \\
\hline 11 & $\begin{array}{l}\text { Keterlibatan peserta didik (Penyajian } \\
\text { materi bersifat interaktif dan } \\
\text { partisipatif) }\end{array}$ & & & $\sqrt{ }$ & & 3 & & & $\sqrt{ }$ & & 3 \\
\hline 12 & Berpusat pada peserta didik & & & & $\sqrt{ }$ & 4 & & $\sqrt{ }$ & & & 2 \\
\hline 13 & Menciptakan komunikasi interaktif & & & $\sqrt{ }$ & & 3 & & $\sqrt{ }$ & & & 2 \\
\hline 14 & $\begin{array}{l}\text { Kesesuaian dengan karakteristik mata } \\
\text { kuliah }\end{array}$ & & & & $\sqrt{ }$ & 4 & & & $\sqrt{ }$ & & 3 \\
\hline 15 & $\begin{array}{l}\text { Kemampuan memunculkan umpan } \\
\text { balik untuk untuk evaluasi diri (tiap } \\
\text { modul berisi rangkuman dan latihan } \\
\text { soal) }\end{array}$ & & & $\sqrt{ }$ & & 3 & & & $\sqrt{ }$ & & 3 \\
\hline Sul & total skor komponen penyajian & & & & & 49 & & & & & 44 \\
\hline $\mathbf{P r}$ & sentase & & & & & $81,67 \%$ & & & & & $73,33 \%$ \\
\hline
\end{tabular}


Tabel 7. Tabulasi Skor Komponen Kebahasaan

\begin{tabular}{|c|c|c|c|c|c|c|c|c|c|c|}
\hline \multirow{3}{*}{ Butir } & \multicolumn{5}{|c|}{ Reviewer I } & \multicolumn{5}{|c|}{ Reviewer II } \\
\hline & \multicolumn{4}{|c|}{ Skala Skor } & \multirow[t]{2}{*}{ Skor } & \multicolumn{4}{|c|}{ Skala Skor } & \multirow[t]{2}{*}{ Skor } \\
\hline & 1 & 2 & 3 & 4 & & 1 & 2 & 3 & 4 & \\
\hline \multicolumn{11}{|l|}{ III. Komponen Kebahasaan } \\
\hline $\begin{array}{l}1 \text { Kesesuaian dengan tingkatan berpikir } \\
\text { dan sosial-emosional peserta didik. }\end{array}$ & & & $\sqrt{ }$ & & 3 & & & $\sqrt{ }$ & & 3 \\
\hline 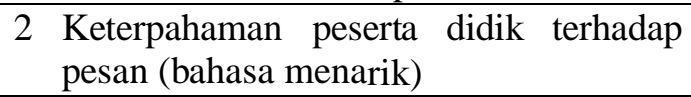 & & & $\sqrt{ }$ & & 3 & & & $\sqrt{ }$ & & 3 \\
\hline $\begin{array}{ll}3 \text { Bahasa yang digunakan mampu } \\
\text { merangsang peserta didik untuk } \\
\text { mempertanyakan dan mencari jawaban } \\
\text { wacana dalam modul (dorongan } \\
\text { berpikir kritis). }\end{array}$ & & & & $\sqrt{ }$ & 4 & & & & $\sqrt{ }$ & 4 \\
\hline 4 Ketepatan struktur kalimat & & & $\sqrt{ }$ & & 3 & & & & $\sqrt{ }$ & 4 \\
\hline 5 Kebakuan istilah & & & $\sqrt{ }$ & & 3 & & & $\sqrt{ }$ & & 3 \\
\hline $6 \begin{array}{l}\text { Kesesuaian dan ketepatan ilustrasi } \\
\text { dengan materi }\end{array}$ & & & $\sqrt{ }$ & & 3 & & & $\sqrt{ }$ & & 3 \\
\hline 7 Ketertautan antara bab/ sub-bab/ alinea & & & & $\sqrt{ }$ & 4 & & & & $\sqrt{ }$ & 4 \\
\hline 8 Konsistensi penggunaan istilah & & & & $\sqrt{ }$ & 4 & & & & $\sqrt{ }$ & 4 \\
\hline 9 Konsistensi penggunaan tanda/lambang & & \multicolumn{3}{|c|}{$\sqrt{ }$} & 3 & & & & $\sqrt{ }$ & 3 \\
\hline $\begin{array}{l}10 \text { Konsistensi penulisan kutipan, rujukan, } \\
\text { daftar pustaka/rujukan, keterangan } \\
\text { gambar, keterangan tabel. }\end{array}$ & & \multicolumn{3}{|c|}{$\sqrt{ }$} & 3 & & & $\sqrt{ }$ & & 3 \\
\hline \multicolumn{5}{|l|}{ Sub total skor kebahasaan } & 33 & & & & & 34 \\
\hline \multirow[t]{4}{*}{ Prosentase } & \multirow{2}{*}{\multicolumn{4}{|c|}{ Skor Total I,II,II }} & $82,50 \%$ & & & & & $85 \%$ \\
\hline & & & & & 94 & & & & & 91 \\
\hline & \multicolumn{4}{|c|}{ Skor maksimum } & 116 & & & & & 116 \\
\hline & & \multicolumn{3}{|c|}{ Prosentase } & $81,03 \%$ & & & & & $78,45 \%$ \\
\hline
\end{tabular}

Berdasarkan penilaian dari dua reviewer, yang dinilai dari segi kelayakan isi, penyajian dan kebahasaan modul ajar yang telah dibuat, terlihat bahwa komponen kelayakan isi memberikan rata-rata skor $12,50(78,13 \%)$ yang termasuk dalam kategori baik, komponen penyajian memperoleh skor rata-rata 46,5 $(77,5)$ dan dikategorikan baik, sedangkan dari segi kebahasaan memperoleh skor rata-rata $33,5(83,75 \%)$ dikategorikan sangat baik. Secara keseluruhan, hasil penilaian reviewer I dan reviewer II terhadap modul ajar ditinjau dari aspek kelayakan isi, penyajian, dan kebahasaan dapat direkapitulasi dan diklasifikasikan sebagai berikut.
Prosentase penilaian reviewer I $81,03 \%$ dan reviewer II 78,45\%. Kemudian kedua prosentase tersebut diperoleh prosentase ratarata menjadi $79,74 \%$. Hal ini menunjukan bahwa dari segi kelayakan, modul ajar dikategorikan baik dan layak digunakan. Selain itu, reviewer I dan reviewer II, juga memberikan catatan-catatan atau masukanmasukan terkait dengan modul ajar yang telah dibuat. Masukan-masukan tersebut pada nantinya digunkan sebagai dasar untuk melakukan perbaikan/revisi sehingga modul menjadi lebih baik. Adapun catatancatatan/masukan-masukan yang diberikan oleh reviewer dapat dilihat pada tabel 8 .

Tabel 8. Catatan-Catatan Terhadap Modul Ajar

\begin{tabular}{ll}
\hline \multicolumn{1}{c}{ Komponen } & \multicolumn{1}{c}{ Catatan } \\
\hline Kelayakan & $\cdot$ Deskripsi isi pada masing-masing bab, dibuat lebih jelas dan menyajikan isi bab secara \\
Isi & keseluruhan. \\
& $\cdot$ Pada modul III dan V, indikator tidak sesuai dengan instrumen tes pada latihan soal. \\
& $\cdot$ Pada modul V hanya terdapat dua indikator, seharusnya lebih dari dua (tiga atau empat). \\
& $\cdot$ Latihan soal tidak disertai kunci jawaban. \\
\hline
\end{tabular}




\begin{tabular}{|c|c|}
\hline Komponen & Catatan \\
\hline Penyajian & $\begin{array}{l}\text { - Cover depan modul ajar kurang menarik. } \\
\text { - Rujukan untuk sumber gambar belum ada. } \\
\text { - Referensinya kurang, terutama berasal dari hasil penelitian dan artikel ilmiah. } \\
\text { - Font untuk penulisan rumus tidak sama. } \\
\text { - Spasinya perlu di tata agar tampilannya menarik. }\end{array}$ \\
\hline Kebahasaan & $\begin{array}{l}\text { - Bahasa yang digunakan kurang mampu merangsang } \\
\text { mempertanyakan dan mencari jawaban sendiri. } \\
\text { - Pada beberapa modul, struktur kalimat kurang teratur. }\end{array}$ \\
\hline
\end{tabular}

Berdasarkan catatan-catatan tersebut di atas dan tahap selanjutnya modul yang telah dibuat direvisi, sesuai dengan masukan atau catatancatatan yang diberikan oleh reveiwer. Setelah direvisi, modul ajar diujicoba pada kelas B sebagai kelas ujicoba.

\section{Implementasi (Uji Efektivitas Produk)}

Setelah tahap validasi, kemudian direvisi dan selanjutnya diujicobakan. Proses ujicoba yang diamati dampak aktivitas, respon

dan kemampuan penalaran matematis mahasiswa. Kemudian setelah itu hasilnya baru dianalisis.

\section{Aktivitas Mahasiswa}

Hasil aktivitas mahasiswa selama proses pembelajaran disajikan dalam Tabel 9. Aktivitas mahasiswa dihitung, berdasarkan jumlah mahasiswa yang melakukan kegiatan, dari total jumlah mahasiswa pada kelas ujicoba sebanyak 23 orang.

Tabel 9. Aktivitas Mahasiswa

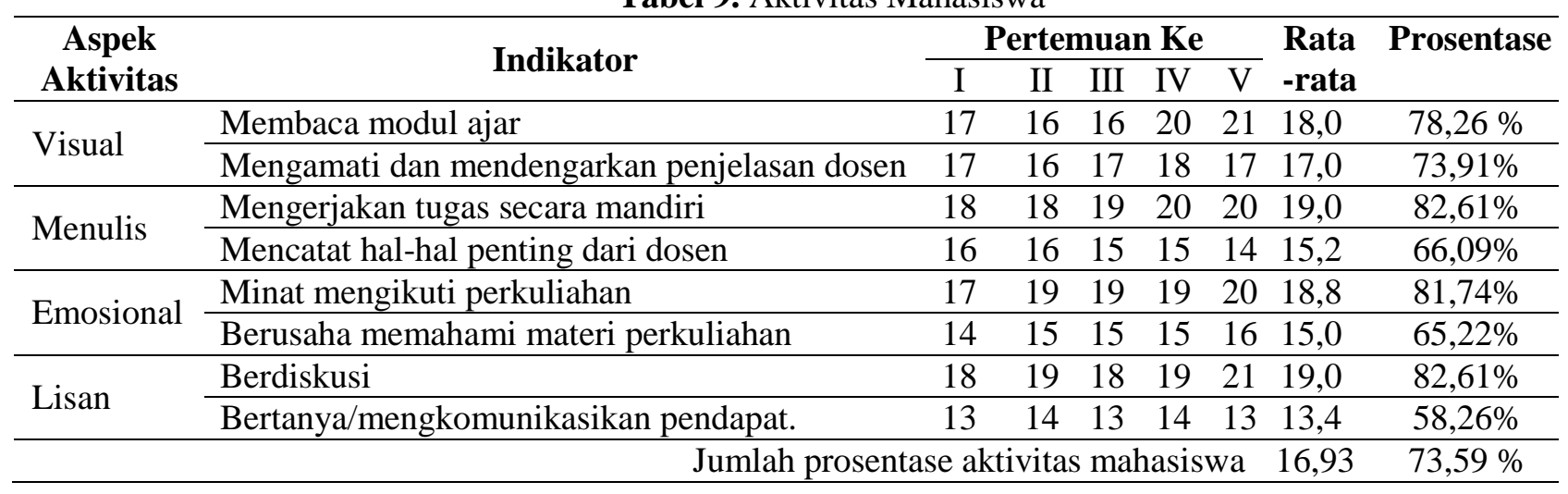

Berdasarkan tabel di atas, aspek aktivitas yang diamati, meliputi aspek aktivitas visual, menulis, emosional, dan aktivitas lisan. Aktivitas tersebut diamati, dari lima kali pertemuan perkuliahan. Berdasarkan observasi, terlihat bahwa prosentase skor ratarata (SR) aktivitas mahasiswa yang membaca modul ajar sebesar 78,26\%, prosentase skor mahasiswa mengikuti perkuliahan $81,74 \%$ dan prosentase skor rata-rata (SR) mahasiswa berusaha memahami materi perkuliahan $65,22 \%$. Pada aspek kegiatan lisan yaitu prosentase skor rata-rata (SR) aktivitas mahasiswa berdiskusi terlihat sebesar $82,61 \%$, dan prosentase skor rata-rata (SR) aktivitas rata-rata (SR) aktivitas mahasiswa yang mendengarkan penjelasan dosen selama perkuliahan sebesar $73,91 \%$, prosentase skor rata-rata (SR) aktivitas mahasiswa mengerjakan tugas secara mandiri $82,61 \%$, dan prosentase skor rata-rata (SR) mencatat penjelasan dosen sebesar $66,09 \%$. Sedangkan prosentase skor rata-rata (SR) minat bertanya atau mengkomunikasikan pendapat sebesar 58,26\%.

Secara keseluruhan prosentase skor ratarata (SR) aktivitas rata-rata mahasiswa yang terlihat selama proses pembelajaran setelah menggunakan modul ajar kompilasi fisika matematika II pada pokok bahasan persamaan 
diferensial sebesar 73,59\%, termasuk kategori baik. Hal ini dapat disimpulkan bahwa aktivitas mahasiswa yang belajar dengan menggunakan modul ajar persamaan diferensial dan aplikasinya, dapat mendukung proses perkuliahan.

\section{Respon Mahasiswa}

Untuk mengetahui respon mahasiswa terhadap penggunaan modul dalam proses pembelajaran menggunakan angket. Angket respon ini diberikan pada mahasiswa setelah mengikuti proses pembelajaran dengan menggunakan modul ajar fisika matematika II pokok bahasan persamaan diferensial. Berdasarkan data respon mahasiswa diperoleh, sebanyak 86,96 \% (20 orang) menyatakan setuju dan $13,04 \%$ (3) sangat setuju. Hal ini menunjukan bahwa modul kompilasi persamaan diferensial sangat berguna. Kemudian dilihat dari respon mahasiswa pada saat penggunaan modul kompilasi dalam perkuliahan, dan aplikasi persamaan diferensial yang terdapat dalam modul, sebanyak 86,96 \% (20 orang) memberikan respon setuju dan $8,69 \%$ (2 orang) memberikan respon sangat setuju, dan hanya $4,35 \%$ (1 orang) yang menjawab kurang setuju. Hal ini dapat disimpulkan bahwa penggunaan modul ajar dan aplikasi materi yang terdapat di dalam modul dapat membantu mahasiswa menyelesaikan permasalahan fisika. Selain itu, sebanyak 91,30\% (21 orang) mahasiswa menyatakan bahwa penggunaan modul ajar dapat meningkatkan kemampuan penalaran dan hanya $8,70 \%$ atau 2 responden menyatakan tidak setuju.

Secara keseluruhan, hasil respon dari 23 mahasiswa diperoleh skor rata-rata $(\bar{s})=$ 28,09, kemudian skor rata-rata tersebut dikonversi menjadi rata-rata nila respon $(\bar{s})$ menjadi 70,23. Kriteria respon mahasiswa ditentukan dengan (a) jika rata-rata respon seluruh responden $(\bar{s})$ lebih besar dari 50, maka subjek ke -i memberi respon positif, (b) jika rata-rata respon seluruh responden $(\bar{S})$ lebih kecil dari 50, maka subjek ke -i memberi respon negatif. Berdasarkan hasil penelitian diperoleh nilai rata-rata respon $(\bar{S})$ sebesar 70,23 lebih besar dari 50, hal ini berarti mahasiswa memberi respon positif. Sehingga dapat disimpulkan bahwa respon mahasiswa terhadap penggunaan modul ajar fisika matematika II pada pokok bahasan persamaan diferensial, memberikan respon positif.

\section{Kemampuan Penalaran Matematis}

Dampak terhadap kemampuan penalaran matematis dilihat dari hasil tes. Hasil tes diperoleh nilai rata-rata 70,87. Kriteria hasil tes penalaran mahasiswa, jika diklasifikasikan ternyata pencapaian penalaran mahasiswa (PPM) lebih besar dari 70 tetapi kurang dari 85. Hal ini dapat dikatakan kemampuan penalaran matematais mahasiswa dikategorikan tinggi. Dilihat dari indikator keefektifannya yaitu, aktivitas, respon, dan kemampuan penalaran mahasiswa dapat disimpulkan bahwa modul ajar fisika matematika pokok bahasan persamaan diferensial dapat dikatakan efektif.

\section{Tahap Disseminate (Pengembangan).}

Pada tahap ini merupakan tahap penggunaan bahan yang telah dikembangkan pada skala yang lebih luas. Tahap disseminate tidak dilakukan, tahap ini akan dilakukan pada penelitian tahun berikutnya atau sebagai penelitian lanjutan.

\section{PENUTUP}

Berdasarkan hasil penelitian dan pembahasan, dapat disimpulkan bahwa modul ajar kompilasi fisika matematika II pokok bahasan persamaan diferensial dikategorikan baik dan layak digunakan, ditinjau dari segi kelayakan isi, penyajian, dan kebahasaan. Aktivitas mahasiswa dikategorikan baik, 
kemampuan penalaran matematis tinggi, dan respon mahasiswa positif terhadap modul ajar kompilasi yang telah dikembangkan. Hal ini menunjukan bahwa modul ajar yang telah dikembangkan efektif ditinjau dari aktivitas, kemampuan penalaran matematis, dan respon mahasiswa.

\section{UCAPAN TERIMA KASIH}

Terima kasih penulis ucapkan kepada Lembaga Penelitian dan Pengabdian Pada Masyarakat Universitas Mataram, lewat dan penelitian PNBP tahun 2017.

\section{REFERENSI}

Arjudin. 2005. Persamaan Diferensial. Program Studi Pendidikan Matematika Jurusan PMIPA FKIP Universitas Mataram.

Amilia, T. N., Andriani, N., Zulherman. 2016. Pengembangan Bahan Ajar Cetak Mata Kuliah Fisika Matematika Pokok Bahasan Bilangan Kompleks di Program Studi Pendidikan Fisika Universitas Sriwijaya. Jurnal Inovasi dan Pembelajaran.Fisika.Dari://ejournal.unsr i.ac.id/index.php/jipf/article/view/3851.

Ellianawati, \& Wahyuni, S. 2012. Pengembangan Bahan Ajar Fisika Matematika Berbasis Self Regulated Learning Sebagai Upaya Peningkatan Kemampuan Belajar Mandiri. Jurnal Pendidikan Fisika Indonesia, 10(2),3340.

Farman. 2017. Pengembangan Perangkat Pembelajaran Dengan Pendekatan Problem Posing Untuk Meningkatkan Kemampuan Penalaran Pada Materi Lingkaran Siswa Kelas VII . Prosiding. Seminar Nasional IKA IKIP Mataram Epistimologi Perkembangan Kurikulum Pendidikan di Indonesia (494-513).

Fatmaryanti, D.,S. 2014. PeningkatanAktivitas dan Hasil Belajar Fisika Matematika I Dengan Metode Brainstorming dan Tutor Teman Sebaya, JRKPF, 1(1).
Gunada, I. W., Sahidu, H., Sutrio. 2015. Pengembangan Perangkat Pembelajaran Fisika Berbasis Masalah Untuk Meningkatkan Hasil Belajar dan Sikap Ilmiah Mahasiswa. Jurnal Pendidikan Fisika dan Teknologi. 1(1), 38-46.

Habibi, \& Herayanti, L., 2016. Pengembangan Buku Ajar Fisika Dasar I Berbasis Self Regulated Learning Sebagai Upaya Memotivasi Mahasiswa Untuk Belajar Mandiri. Jurnal Pendidikan Fisika dan Teknologi. 2(4), 154-158.

Lestari, D. 2013. Diktat Persamaan Diferensial. Jurusan Pendidikan Matematika Fakultas MIPA. Universitas Negeri Yogyakarta

Murdiyanto, T. 2016. Pengembangan Bahan Perkuliahan Kompilasi Mata Kuliah Persamaan Diferensial Elementer Prodi Pendidikam Matematika. Prosiding. Konferensi Nasional Penelitian Matematika dan Pembelajarannya (KNMPPI) Universitas Muhammadyah Surakarta. 12 Maret 2016.

Nuraeni, Z. 2017. Aplikasi Persamaan Diferensial dalam Estimasi Jumlah Populasi. Jurnal Ilmiah Pendidikan Matematika, 5(1), 9-16.

Young, H. D., \& Freedman, R. A., Sadin, T. R., Ford, A. L. 2003. Fisika Universitas. Terjemahan Pantur Silaban. Jakarta: Erlangga.

Septian, A. 2014. Pengaruh Kemampuan prasyarat Terhadap Kemampuan Penalaran Matematis Mahasiswa dalam Matakuliah Analisis Real. Jurnal Kajian Pendidikan. 4(2), 179-188.

Suharnan.2005. Psikologi Kognitif. Surabaya: Penerbit Srikandi.

Wahyudi. 2015. Analisi Hasil Belajar Mahasiswa Pada Pokok Bahasan Hukum Ohm dan Kirchoff dalam Matakuliah Elektronika Dasar I. Jurnal Pendidikan Fisika dan Teknologi. 1(2), 129-134. 